\title{
REVITALISASI KEARIFAN LOKAL DALIHAN NA TOLU MASYARAKAT MUSLIM MANDAILING DALAM MENJAGA HARMONISASI LINGKUNGAN HIDUP
}

\author{
Lelya Hilda \\ Fakultas Tarbiyah dan Ilmu Keguruan IAIN Padangsidimpuan \\ Jl. H.T. Rizal Nurdin, Km. 4.5 Sihitang, Padangsidimpuan, 22733 \\ e-mail: lelya.hilda@gmail.com
}

\begin{abstract}
Abstrak: Kearifan lokal dalihan na tolu pada masyarakat Mandailing terancam terdegradasi oleh pengaruh globalisasi. Nilai-nilai kearifan lokal memiliki makna yang dalam, baik dari segi adat maupun agama, sehingga perlu dilestarikan untuk menciptakan masyarakat yang peduli lingkungan. Tulisan ini bertujuan untuk mengetahui kearifan lokal dalihan na tolu dalam masyarakat Mandailing dan cara mempertahankannya dalam menjaga keharmonisan lingkungan hidup. Data dikumpulkan melalui wawancara dan observasi. Keharmonisan lingkungan hidup masyarakat Mandailing dengan kearifan lokal dalihan na tolu yang melindungi lingkungan, seperti marsialapari, harangan rarangan, lubuk larangan dan bahasa daun harus dijaga kelestariannya. Kearifan lokal ini perlu disosialisasikan pada generasi penerus dengan mempelajarinya mulai tingkat dasar sampai perguruan tinggi sehingga tetap terjaga kelestariannya. Penanaman nilai-nilai agama merupakan faktor utama dalam mempertahankan kearifan lokal dalihan na tolu.
\end{abstract}

\begin{abstract}
Local Wisdom Dalihan Na Tolu of Muslim Mandailing Community in Preserving Environment Harmony. Local wisdom Dalihan $\mathrm{Na}$ Tolu on Muslim Mandailing community relegation due to the influence of globalization. The values of local wisdom inherited conveys meaning in terms of both traditional and religious, so it needs to be preserved to create a society that cares about the environment. This paper aims to determine the Local Wisdom dalihan na tolu in Mandailaing Community and how to maintain dalihan na tolu in maintaining the harmony of the environment. Data were collected through interviews and observation. Mandailing community environmental harmony with local wisdom dalihan na tolu with protecting the environment should be preserved as marsialapari, harangan rarangan, lubuk larangan and bahasa daun. So it is necessary to socialize the next generation Mandailing community and revive local wisdom by learning start elementary to college level so that maintained continuity. Planting of religious values is one of the main factors in maintaining local wisdom dalihan na tolu.
\end{abstract}

Kata Kunci: kearifan lokal, Muslim Mandailing, dalihan na tolu, lingkungan 


\section{Pendahuluan}

Persoalan lingkungan hidup dari hari ke hari semakin kompleks. Dewasa ini, degradasi lingkungan hidup semakin meningkat. Manusia semakin terancam dan merasa tidak nyaman lagi dalam kehidupannya. Faktor penyebab semua ini adalah sebagai akibat ulah manusia yang serakah, kapitalistik dan antroposentrik.

Indonesia kaya dengan budaya kearifan terhadap lingkungan hidup. Akan tetapi, kearifan lokal yang ada dalam masyarakat terdegradasi. Hal ini diakibatkan oleh norma dan etika terhadap lingkungan hidup yang diwariskan secara turun-temurun itu terancam oleh gaya hidup materialis hedonis yang konsumtif dan mengejar kesenangan sesaat semata. Fenomena ini sangat terlihat di dalam masyarakat, dengan adanya profesi yang berorientasi bisnis dan kurang peduli lingkungan.

Menurut Zulkifli B. Lubis bahwa upaya mengintegrasikan aspek kebudayaan dan komunitas pemilik kebudayaan dalam kerangka konservasi sumber daya hayati menjadi sesuatu yang urgen secara teoritik. Maurizio Farhan Ferrari mengemukakan bahwa sampai sejauh ini sudah diakui secara luas bahwa kebijakan-kebijakan dan proyek konservasi yang tidak mempertimbangkan hak-hak dan kebutuhan-kebutuhan dari penduduk pribumi dan komunitas lokal akan membiakkan konflik dan dalam banyak kasus akan gagal. Badanbadan dunia seperti WCPA, IUCN dan WWF telah menerima prinsip-prinsip ini dan telah mengembangkan panduan internal untuk memberikan penghormatan terhadap hak-hak komunitas pribumi itu. Namun, yang menjadi soal sejauh ini adalah lambannya proses untuk mewujudkan prinsip itu di dalam praktik nyata di lapangan. ${ }^{1}$

Indonesia merupakan negara kaya akan keanekaragaman budaya, etnis, suku dan ras dengan lebih dari 389 suku bangsa yang memiliki adat istiadat, bahasa, tata nilai dan budaya yang berbeda-beda. Potensi aset budaya memiliki nilai sejarah dan merupakan rangkaian pusaka yang perlu dilestarikan, dijaga kesinambungan dan dijadikan pijakan dalam perencanaan dan perancangan lingkungan binaan berkelanjutan. Namun, adanya globalisasi dapat mengancam eksistensi kearifan lokal dari rangkaian pusaka tersebut.

Masuknya kebudayaan asing menyebabkan kebudayaaan warisan nenek moyang yang memiliki nilai-nilai luhur yang harusnya dipertahankan hilang begitu saja. Generasi berikutnya tidak lagi mengetahui warisan luhur tersebut, maka diperlukan usaha untuk membendung pengaruh-pengaruh asing yang menyebabkan pengaruh negatif harus dibentengi dengan membangkitkan nilai-nilai warisan luhur dari nenek moyang.

Setiap etnis memiliki kebudayaan yang berbeda-beda, seperti halnya suku Batak salah satunya Mandailing. Masyarakat Muslim Mandailing sebagai salah satu sub suku Batak memiliki perangkat struktur dan sistem sosial yang merupakan warisan nenek moyang.

${ }^{1}$ Maurizio Farhan Ferrari, "Community Conserved Areas in Southeast Asia," Final Report for IUCN, 2002. 
Struktur dan sistem sosial tersebut mengatur tata hubungan sesama anggota masyarakat, baik yang merupakan kerabat dekat, kerabat luas, saudara semarga, maupun beda marga serta masyarakat umum. Struktur sosial yang dimiliki masyarakat Muslim Mandailing pada hakikatnya berdasarkan garis keturunan bapak yang memiliki tiga unsur struktur sosial yang lebih dikenal dengan sebutan dalihan na tolu.

Dalihan na tolu yaitu kahanggi (teman semarga), anak boru (pihak pengambil isteri), dan mora (pihak pemberi istri). Dalihan na tolu dianalogikan dengan tiga tungku, yang biasanya batu yang dipakai untuk menyangga periuk atau kuali ketika sedang memasak. Jarak ketiga tungku adalah sama, sehingga ketiganya dapat menyangga dengan kokoh alat memasak di atasnya. Titik tumpu periuk atau kuali berada pada ketiga tungku berada bersama-sama dan mendapat tekanan berat yang sama. Periuk dapat diartikan sebagai beban kewajiban bersama atau sebagai kerja bersama atau lazim yang disebut horja. Seluruh tatanan dalihan na tolu mendapat bagian dalam horja. Karena itu, dalihan na tolu diartikan dengan tiga tungku, menunjukkan kesamaan peran, kewajiban dan hak dari ketiga unsur dalam dalihan na tolu.

Dalihan na tolu sebagai basic structure adat Mandailing sangat dominan dalam pelaksanaan prosesi adat. Nenek moyang di zaman dahulu selalu belajar dan mengambil hikmah filosofis dari alam lingkungan mereka sendiri. Benda-benda dan tumbuh-tumbuhan yang ada di sekeliling menjadi guru yang sangat berharga dan berpengaruh besar dalam kehidupan masyarkat pada waktu itu dan kenyataannya dalam banyak hal masih dipakai dan dilestarikan sampai saat ini sepanjang tidak bertentangan dengan agama Islam. ${ }^{2}$

Munculnya dalihan na tolu adalah akibat hubungan kekerabatan yang terjadi karena perkawinan antara marga. Dalihan na tolu adalah suatu sistem adat yang sangat terbuka, demokratis dan berkembang. Anak laki-laki dalam suatu keluarga tidak selalu harus mengawini boru tulang-nya, tetapi dia juga dapat kawin dengan gadis dari marga-marga yang lain, sehingga dalihan na tolu tersebut berkembang dan meluas. ${ }^{3}$

Keseimbangan dan keharmonisan masing-masing unsur terlihat pada ungkapanungkapan masyarakat Mandailing tersebut manat sanga pe jamot, marhamaranggi, elek marboru, dan hormat marmora, artinya masyarakat Mandailing harus berhati-hati kepada kahanggi, berlaku sayang kepada anak boru, dan selalu hormat kepada mora. Ungkapan lain dan makna yang sama sagama markahanggi, holong maranak boru, dan sangap marmora. Ketiga unsur kekerabatan ini terjadi karena hubungan darah dan hubungan perkawinan. ${ }^{4}$

${ }^{2}$ Zainal Efendi Hasibuan dan S.T.B. Perkasa Alam, Studi Komprehensif Adat Budaya Batak Angkola (t.t.p.: t.p., 2013), h. 54.

${ }^{3}$ Ibid., h. 55.

${ }^{4}$ Abbas Pulungan, "Peranan Dalihan Natolu dalam Proses Interaksi Antara Nilai-Nilai Adat dengan Islam pada Masyarakat Mandailing dan Angkola Tapanuli Selatan" (Disertasi: IAIN Sunan Kalijaga Yogyakarta, 2003), h. 2. 
Orang akan menanyakan mengapa tidak memakai dua atau empat dalihan kemudian menjadi dalihan na dua atau dalihan na opat?. Jawabannya adalah keseimbangan, keselarasan dan keharmonisan tidak diperoleh dengan dua atau empat penyangga periuk, dandang atau kuali ketika memasak. Demikian juga tatanan masyarakat tidak akan seimbang apabila disangga oleh dua atau empat penyangga. ${ }^{5}$ Bagi masyarakat Muslim Mandailing, keharmonisan kehidupan masyarakat adat akan diperoleh dengan memakai tiga penyangga. Ini yang disebut dalam kemasyarakatan sebagai social equilibrium. Sosiolog Newell LeRoy Sims mendefinisikan sosial equiblirium sebagai a state of sosial-cultural integration in which all parts are functioning harmoniously, artinya keadaan sosio-kultural yang terintegrasi di mana semua komponen masyarakat berfungsi secara harmonis. ${ }^{6}$ Dua penyangga tidak kukuh, mudah goyah, sedangkan empat penyangga dapat menimbulkan perpecahan, karena sangat mungkin akan terjadi perbedaan pendapat yang membelah dua kelompok itu. Karena itu, yang paling ideal adalah tiga penyangga, atau tiga tungku, sehingga masing-masing menjaga dirinya sebagai bagian dari keselarasan. Dengan kearifan lokal dalihan na tolu, diharapkan kepedulian terhadap lingkungan hidup akan tercipta, sehingga akan terjaga harmonisasi. Keselarasan, kerja sama dan saling menghargai sebagai sifat yang patut ditumbuhkan untuk saling peduli dan komitmen bahwa lingkungan hidup adalah tempat yang harus dijaga dan dilestarikan untuk mencapai keselarasan hidup.

Tujuan kajian ini adalah untuk mengetahui kearifan lokal dalihan na tolu dalam masyarakat Muslim Mandailing dalam menjaga keharmonisan lingkungan hidup dan cara mempertahankan dalihan na tolu dalam menjaga keharmonisan lingkungan hidup.

\section{Kearifan Lokal, Dalihan Na Tolu, Harmonisasi Lingkungan Hidup}

Menurut M. Akhmar dan Syarifudin, kearifan lokal merupakan tata nilai atau perilaku hidup masyarakat lokal dalam berinteraksi dengan lingkungan tempat hidupnya secara arif. Semua bentuk kearifan lokal ini dihayati, dipraktikkan, diajarkan dan diwariskan dari generasi ke generasi sekaligus membentuk pola perilaku manusia terhadap sesama manusia, alam maupun gaib. ${ }^{7}$ Francis Wahono dalam Suhartini menjelaskan bahwa kearifan lokal adalah kepandaian dan strategi-strategi pengelolaan alam semesta dalam menjaga keseimbangan ekologis yang sudah berabad-abad teruji oleh berbagai bencana dan kendala serta keteledoran manusia. Kearifan lokal tidak hanya berhenti pada etika, tetapi sampai pada norma dan tindakan dan tingkah laku, sehingga kearifan lokal dapat menjadi seperti

${ }^{5}$ Basyral Hamidy Harahap, Siala Sampagul (Nilai-Nilai Luhur Budaya Masyarakat Kota Padangsidimpuan) (Bandung: Pustaka, 2004), h. 23.

${ }^{6}$ Ibid., h. 24.

${ }^{7}$ Lihat Suhartini, "Kajian Kearifan Lokal Masyarakat dalam Pengelolaan Sumber Daya Alam dan Lingkungan," makalah Prosiding Seminar Nasional Penelitian, Pendidikan dan Penerapan MIPA, Fakultas MIPA, Universitas Negeri Yogyakarta, 16 Mei 2009. 
religi yang mempedomani manusia dalam bersikap dan bertindak, baik dalam konteks kehidupan sehari-hari maupun menentukan peradaban manusia yang lebih jauh. ${ }^{8}$

\section{Dalihan Na Tolu}

Asal mula adat Dalihan Na Tolu adalah rasa kasih sayang (holong). Kasih sayang akan membawa keakraban (holong maroban domu). Kasih sayang sesama Muslim harus terus dipelihara seperti hadis berikut, "sesungguhnya kasih sayang itu cabang (penghubung) kepada Allah SWT. Barang siapa yang menyambungnya, maka Allah akan menyambung (kasih sayang-Nya) dengannya. Dan barang siapayang memutuskannya, maka Allah akan memutus (kasih sayang-Nya) dengannya" (HR. Bukhârî).

Kasih sayang yang dimaksud oleh nenek moyang masyarakat Mandailing bukan hanya sebagai hiasan atau slogan saja, tetapi harus dilaksanakan dalam kehidupan warga masyarakat. Untuk melaksanakan rasa kasih sayang (holong) sesama masyarakat Mandailing itu tentu harus ada mekanisme berupa satu sistem nilai sosial atau sistem yang digunakan untuk melaksanakan kasih sayang dalam kehidupan bermasyarakat. Sistem sosial tersebut didasarkan pada kelompok kekerabatan yang diikat oleh pertalian darah dan pertalian perkawinan. Kelompok kekerabatan inilah yang dijadikan sebagai tumpuan (dalihan na tolu).

Dalihan na tolu ada beberapa unsur. Pertama, kahanggi adalah satu kelompok kerabat satu marga. Istilah-istilah lain yang menyangkut kerabat kahanggi antara lain, sa ama saina, marakang maranggi, sa ama saoppu, saparamaan, saparompuan, sabona atau sahaturan. Kahanggi dan kahanggi pareban sidang adat berada dalam satu kubu, satu kelompok kerabat sidang adat, pareban ini disebut hombar suhut apabila berlainan marga. Kahanggi atau suhut adalah suatu kelompok yang semarga atau yang mempunyai garis keturunan yang sama dalam satu huta (kampung) yang merupakan bona bulu (pendiri kampung). ${ }^{9}$ Kedua, anak boru adalah kelompok kerabat yang mengambil isteri dari kerabat mora. Anak boru juga dapat didefinisikan sebagai saudara perempuan dari ayah suhut. Ketiga, mora atau hulahula adalah kelompok kerabat yang memberi boru untuk dipersunting menjadi isteri oleh anak boru atau mora adalah tingkat keluarga yang oleh suhut mengambil boru (istri) dari kelompok ini. Dari pengertian ini, dapat disimpulkan bahwa mora adalah setiap keluarga dari istri. ${ }^{10}$

Norma-norma adat, ajaran agama, partuturan, dalihan na tolu, dan nilai-nilai yang melahirkan suasana keharmonisan serta kepekaan terhadap perubahan lingkungan hidup merupakan nilai-nilai yang disosialisasikan. Ketertiban hubungan tiga unsur dalihan na

${ }^{8}$ Ibid., h. 207.

${ }^{9}$ Tim Penulis Parsadaan Marga Harahap Dohot Anak Boruna, Horja Adat Istiadat Dalihan Natolu (Jakarta: Persadaan Marga Harahap Dohot Boruna, 1991), h. 98-102.

${ }^{10}$ Ibid., h. 101. 
tolu dijaga dan dipelihara. Keharmonisan hubungan antara unsur berlangsung atas dasar keseimbangan yang serasi antara hak dan kewajiban.

\section{Harmonisasi Lingkungan Hidup}

Perhatian ilmuwan sosial khususnya antropologi terhadap praktik-praktik pengelolaan sumber daya alam oleh komunitas lokal sudah lama berkembang. Salah satu perspektif kajian yang pernah populer adalah perspektif fungsionalisme dan neo-fungsionalisme. Banyak kasus kajian yang memperlihatkan bahwa komunitas lokal mampu membangun suatu interaksi yang adaptif dengan lingkungan alam. Pada tahun 1980-an misalnya, ada kajian dari R.N.H. Bulmer, mengenai praktik konservasi tradisional di Papua New Guinea. Bulmer, mengemukakan bahwa kepercayaan dan pantangan ritual memungkinkan penduduk Papua New Guinea mengelola dan memanfaatkan sumber daya yang ada di hutan sesuai asas-asas konservasi. Dalam kaitan ini, aspek religius dipandang sebagai faktor yang fungsional membatasi tindakan-tindakan eksploitasi dan kerusakan. ${ }^{11}$

Lingkungan hidup adalah kesatuan ruang dengan semua benda, daya, keadaan, dan makhluk hidup, termasuk manusia dan perilakunya, yang mempengaruhi alam itu sendiri, kelangsungan perikehidupan, dan kesejahteraan manusia serta makhluk hidup lain. Upaya pengelolaan lingkungan hidup dan upaya pemantauan lingkungan hidup adalah pengelolaan dan pemantauan terhadap usaha dan atau kegiatan yang tidak berdampak penting terhadap lingkungan hidup yang diperlukan bagi proses pengambilan keputusan tentang penyelenggaraan usaha dan atau kegiatan.

Permasalahan yang masih terus dihadapi sampai saat ini dalam perbaikan kualitas lingkungan hidup antara lain adalah masih terjadinya pencemaran dan kerusakan lingkungan di beberapa wilayah dan ekosistem, yang melebihi daya dukung dan kemampuan lingkungan untuk pemulihan/memperbaiki sendiri. Desentralisasi pengelolaan lingkungan dan adanya konflik kepentingan dalam pembangunan di berbagai sektor sering menyebabkan beban terhadap lingkungan dan kerusakan terhadap keanekaragaman hayati. Pengelolaan lingkungan yang masih bersifat sektoral dan parsial, serta kurangnya koordinasi antar pemangku kepentingan yang menimbulkan kurang efektifnya pengelolaan. Bervariasinya ketersediaan dan tingkat akurasi data dan informasi di berbagai institusi menyebabkan kemungkinan terjadinya ketidaktepatan dalam pembuatan rencana, serta monitoring dan evaluasi kualitas lingkungan hidup. Upaya pelestarian lingkungan masih terkendala dengan rendahnya kesadaran masyarakat, pendekatan pelaksanaan pembangunan yang kurang peduli terhadap lingkungan, serta kebijakan pengelolaan lingkungan yang belum terintegrasi dengan baik dengan perencanaan pembangunan lainnya (lingkungan yang

${ }^{11}$ R.N.H. Bulmer, "Traditional Conservation Practices in Papua New Guinea," dalam L. Morauta et.al. (ed.) Traditional Conservation in Papua New Guinea: Implication for Today (Papua New Genea: t.t.p., 2013), h. 82. 
diperlakukan sebagai eksternalitas). Meningkatnya potensi bencana ekologis dan perubahan iklim global. Serta perubahan fungsi kawasan konservasi karena pembangunan sektor lain serta pemekaran wilayah. ${ }^{12}$

Paradigma Islam tentang lingkungan, menurut Sardar, pertama kali berpijak kepada konsep tauhid. Tauhid, menurut Sardar, adalah poros di mana segala aktivitas kehidupan harus berpusat padanya. Tauhid mengandung pengertian keesaan Tuhan. Ini menjadi nilai yang universal mencakup keseluruhan jika kesatuan ini ditegaskan ke dalam kesatuan kemanusiaan, kesatuan manusia dengan alam, dan kesatuan pengetahuan dan nilai. ${ }^{13}$ Dari tauhid ini kemudian timbul konsep khilafah dan amanah, yang di bawah kerangka ini keseluruhan etika lingkungan Islam berada. Manusia tidaklah bebas begitu saja dari Tuhan, tetapi harus bertanggungjawab kepada Tuhan atas segala aktivitas sains dan teknologinya. Bumi beserta isinya adalah suatu amanat dari Tuhan yang harus dijaga dan dipelihara. ${ }^{14}$ Manusia dapat menggunakan amanat ini untuk kepentingannya tetapi tidak memiliki hak mutlak terhadap segalanya. Amanat harus dijaga dan kemudian dikembalikan kepada pemiliknya. Manusia bertanggungjawab atas segala penyimpangan dan penyalahgunaan terhadap amanat tersebut dan jika ini terjadi, maka ia harus menerima risiko baik di dunia maupun di akhirat.

Kelestarian dan keharmonisan alam jagat raya ini telah dijamin oleh Allah SWT. Selanjutnya, Allah memberikan tantangan bagi manusia agar meneliti andai manusia menemukan cacat, ketidaksempurnaan atau kerusakan di dalam ciptaan-Nya. Allah Swt. berfirman, "Yang telah menciptakan tujuh langit berlapis-lapis. Kamu sekali-kali tidak melihat pada ciptaan Tuhan yang Maha Pemurah sesuatu yang tidak seimbang. Maka lihatlah berulangulang, Adakah kamu lihat sesuatu yang tidak seimbang? Kemudian pandanglah sekali lagi niscaya penglihatanmu akan kembali kepadamu dengan tidak menemukan sesuatu cacat dan penglihatanmu itu pun dalam keadaan payah." ${ }^{15}$ Ayat ini memberikan pemahaman bahwa al-Qur'an sangat menggalakkan manusia memperhatikan bahkan meneliti alam dan menemukan ayat-ayat yang mengatur fenomena alam.

\section{Metode Penelitian}

Penelitian ini menggunakan pendekatan kualitatif deskriptif, yaitu penelitian yang

\footnotetext{
${ }^{12}$ Yusuf Hilmi Adisendjaja, "Analisis Dampak Pembangunan Terhadap Lingkungan," Musyawarah Kerja Nasional Jaringan Himpunan Mahasiswa Biologi Indonesia (JHMBI) dan Seminar Lingkungan Hidup di Bandung, 29 September 2003, h. 9-10.

${ }^{13} Z$ Ziauddin Sardar, "Why Islam Needs Islamic Science," dalam New Scientist, Vol. 94, 1982, h. 7 .

${ }^{14}$ Ziauddin Sardar, Islamic Futures: The Shape of Ideas to Come (London: Mansell Publishing, 1985), h. 226.

${ }^{15}$ Departemen Agama RI, Al-Qur'an dan Terjemannnya (Surabaya: Mekar Surabaya, 2004), h. 617.
} 
dilakukan dengan mendeskripsikan fenomena secara menyeluruh/komprehensif. Jenis penelitian ini termasuk penelitian riset lapangan (field research) yaitu dengan menggunakan informasi yang diperoleh dari informan melalui angket, wawancara, dan observasi. ${ }^{16}$ Dalam penelitian ini ada dua jenis data yang diperlukan yaitu data primer dan data sekunder. Data primer adalah data yang dibutuhkan dalam penelitian ini, data ini diperoleh dari wawancara dengan tokoh-tokoh adat, hatobangon, cerdik pandai dan masyarakat Muslim Mandailing, sedangkan data sekunder yaitu data pendukung yang diperoleh dari dokumen dan sumber-sumber lain yang mendukung penelitian. Untuk memperoleh data dan informasi yang dibutuhkan, maka akan digunakan instrumen pengumpulan data seperti wawancara dengan tokoh-tokoh adat, hatobangon, cerdik pandai dan masyarakat Mandailing; dan observasi yaitu melaksanakan pengamatan langsung terhadap pelaksanaan dalihan na tolu.

\section{Hasil dan Pembahasan}

Dalihan na tolu merupakan kearifan lokal yang patut dikembangkan dan dilestarikan di masyarakat Muslim Mandailing karena kebersamaan antara mora, kahanggi dan anak boru ibarat tungku yang memiliki tugas yang sama supaya berdiri kokoh. Dengan ikatan yang kuat antara sesama ini akan membentuk masyarakat yang tahu fungsi dan tugasnya masing-masing. Ibarat suatu pemerintahan, ada pimpinan dan bawahan yang harus saling mengisi supaya suatu pekerjaaan dapat dikerjakan dengan suatu keberhasilan. Bila seseorang berada pada kedudukan mora, maka dia lah yang bertanggungjawab sebagai ketua/pimpinan, dan anak boru sebagai pekerja yang bertanggung jawab menyelesaikan pekerjaan. Kearifan lokal dalihan na tolu pada masyarakat Muslim Mandailing sangat erat hubungannya dengan harmonisasi lingkungan yang harus terus dijaga dan dimanfaatkan.

Dari hasil wawancara dengan Nurintan (Hatobangon), dinyatakan bahwa dalihan na tolu sangat erat hubungannya dengan harmonisasi lingkungan hidup karena dalam suatu masyarakat ikatan dalihan na tolu tetap ada, apabila dalihan na tolu dijalankan sesuai dengan fungsi masing-masing, maka kerjasama saling membantu menyelesaikan pekerjaan akan terlaksana dengan baik. Begitu juga dalam masyarakat Muslim Mandailing ikatan dalihan na tolu tersebut dapat digunakan untuk membentuk keharmonisan lingkungan hidup. ${ }^{17}$

Tongku Sariypuddin menyatakan bahwa dalihan na tolu hubungannya dengan harmonisasi lingkungan hidup sesuai dengan fungsi masing-masing dari komponen yang terdapat di dalihan na tolu misalnya mora, kahanggi dan anak boru. Bila fungsi masing-masing dijalankan dengan benar, maka tidak akan ada persoalan yang tidak dapat dilaksanakan, karena lingkungan

${ }^{16}$ Sugiono, Memahami Penelitian Kualitatif (Bandung: Alfabeta, 2007), h. 3.

${ }^{17}$ Nurintan, salah satu tokoh Hatobangon di daerah Mandailing yang sering perwakilan dari masyarakat untuk markobar adat pada Horja di daerah Mandailing, Wawancara, Sabtu tanggal 6 Juni 2015. 
hidup adalah milik bersama, maka tugas bersama juga lah yang akan melindunginya dari kerusakan. ${ }^{18} \mathrm{Hal}$ ini sesuai dengan ayat al-Qur'an berikut, "Telah tampak kerusakan di darat dan di laut disebabkan karena perbuatan tangan manusia; Allah menghendaki agar mereka merasakan sebagian dari (akibat) perbuatan mereka, agar mereka kembali (ke jalan yang benar). Katakanlah (Muhammad), "Bepergianlah di bumi lalu lihatlah bagaimana kesudahan orang-orang dahulu. Kebanyakan dari mereka adalah orang-orang yang mempersekutukan (Allah)." ${ }^{19}$ Ayat tersebut menjelaskan segala sesuatu tidak sia-sia dan melarang manusia untuk berbuat kerusakan di bumi, hal ini mengandung makna keseimbangan. Keseimbangan yang diciptakan Allah SWT. dalam suatu lingkungan hidup akan terus berlangsung dan baru akan terganggu apabila terjadi suatu keadaan luar biasa. Keadaan luar biasa itu terjadi dalam bentuk bencana alam.

Sedangkan Malim Muda menyatakan kerusakan yang terjadi sekarang ini adalah akibat perbuatan manusia, sehingga dengan keserakahan manusia dalam mengeksploitasi sumber alam menimbulkan tidak keseimbangan dalam lingkungan. Tetapi dengan dalihan na tolu tetap terjaga, maka pemerintah juga akan mudah mengayomi masyarakat. Karena dalam suatu lingkungan masyarakat akan berkumpul masyarakat-masyarakat dalihan na tolu. ${ }^{20}$

Kearifan lokal dengan tetap mengembangkan adat dalihan na tolu pada masyarakat Mandailing dapat dilihat dari sifat-sifat yang tetap dilestarikan antara lain:

\section{Marsialapari Tradisi Gotong Royong Masyarakat Muslim Mandailing}

Masyarakat Mandailing yang berada di Sumatera Utara juga memiliki budaya atau tradisi-tradisi yang di dalamnya mengandung aspek tolong-menolong. Mereka berusaha tetap mempertahankan tolong-menolong yang di dalamnya mengandung nilai-nilai luhur yang diwarisi dari generasi ke generasi. Hal ini dapat terlihat pada tradisi-tradisi pengelolaan lingkungan. Salah satunya masyarakat Mandailing masih melakukan tradisi marsialapari.

Dalam tradisi marsialapari tersebut ada tradisi bergotong-royong dalam mengerjakan sawah, sehingga pekerjaan yang berat akan terasa ringan apabila dikerjakan bersamasama. Tradisi marsialapari merupakan tradisi dalihan na toluyang menganut saling memikul, bahu-membahu, seperti pepatah berat sama dipikul ringan sama dijinjing.

Menurut Nasution, ketentuan-ketentuan adat di Mandailing sudah banyak tunduk kepada hukum Islam, seperti masalah waris, kematian dan kelahiran, kecuali perkawinan

${ }^{18}$ Tongku Sariypuddin, salah satu tokoh adat Mandailing, Wawancara, Sabtu tanggal 6 Juni 2015. h. 576.

${ }^{19}$ Departemen Agama RI, Al-Qur'an dan Terjemahannya (Surabaya: Mekar Surabaya, 2004),

${ }^{20}$ Malim Muda, Salah Satu Tokoh Agama Masyarakat Mandailing, Wawancara Sabtu, tanggal 13 Juni 2015. 
masih berpegang pada masalah adat. Karena di Mandailing ada pepatah obar adat dohot ugamo, artinya adat dan agama bisa berdampingan. ${ }^{21}$

Gotong royong juga sangat sesuai dengan ajaran Islam. Islam menginginkan umatnya saling mencintai, menyayangi dan saling berbagi, itu sangat sejalan dengan prinsip gotong royong. Semangat gotong royong dalam Islam juga bisa dijadikan ukuran keimanan seseorang, dalam hal ini Rasulullah SAW. bersabda dalam hadis yang diriwayatkan Bukhârî, Muslim, Tirmizi, dan Nasâ'i, "tidak beriman salah seorang di antara kamu sampai ia mencintai saudaranya sama dengan mencintai dirinya sendiri."

Berbagai krisis yang melanda kehidupan manusia di segenap penjuru bumi sebenarnya bisa dikaitkan dengan kerancuan beragama dan kegalauan berbudaya, yang ujungnya menyebabkan kekacauan berkarya. Amanah untuk mengatasi hal yang runyam ini dilimpahkan kepada bangsa Indonesia. Perbaikan dan pembaruan yang sistematis sebaiknya beranjak dari dasar, maka pada tingkat internasional bermula dari haji, pada tingkat nasional berawal dari dalihan na tolu.

Hasil wawancara dengan cerdik pandai Marahamdan menyatakan bahwa:

Marsialapari dalam dalihan na tolu dapat tercipta karena fungsi masing-masing dari mora, kahanggi mapun anak boru saling berkaitan dan terjadinya siklus yang pada suatu saat mora bisa jadi kahanggi, kahanggi jadi anak boru ataupun sebaliknya, sehingga fungsi masing-masing harus dimiliki setiap orang untuk melaksanakan tugasnya di manapun berada. Bila hal ini terjadi, maka persaudaraan sesama akan tercipta, keharmonisan dalam kekeluargaan ataupun lingkungan akan terjaga, sehingga kerukunan antar umat bergama, kelancaran dalam pekerjaan akan terlaksana dengan baik. Beliau juga menyampaikan bahwa adat dalihan na tolu harus tetap dipertahankan dan diturunkan kepada generasi penerus karena dengan mempelajari dan melaksanakan dengan baik maka tingkat persaudaraan, kebersamaan dan ketaatan beribadah juga akan tercipta. Karena dalam adat dalihan natolu memuat ajaran-ajaran Islam yang harus tetap dipertahankan. ${ }^{22}$

Adapun tujuan dan guna pelaksanaan dalihan na tolu adalah apabila seseorang mendirikan suatu pekerjaan maka kahanggi, anak boru, mora, sangat perlu. Harus memberitahukannya kepada tiga belah pihak, yaitu kahanggi, anak boru dan mora dan dapat mempersatukannya masyarakat desa dan budaya adat, kemudian juga dapat memperkuat hubungan silaturahmi dohot parkouman masyarakat lainnya. Dengan menjalankan syariat agama bersama-sama dengan adat ini maka harmonisasi lingkungan hidup akan tercapai. ${ }^{23}$

Selain itu, dari hasil pengamatan bahwa adat dalihan na tolu bertujuan sebagai berikut.

\footnotetext{
${ }^{21}$ Pandapotan Nasution, Uraian Singkat Tentang Adat Mandailing dan Tata Cara Perkawinannya (Jakarta: Widya Press, 1994), h. VII

${ }^{22}$ Marahamdan Harahap, salah satu tokoh cerdik pandai, Wawancara, Sabtu, tanggal 13 Juni 2015.

${ }^{23}$ Nurintan dengan salah satu Hatobangon, Wawancara, Minggu 14 Juni 2015.
} 
Pertama,mendekatkan persaudaraan supaya menanamkan nilai-nilai akidah secara emosional kepada masyarakat. Kedua, memberikan contoh teladan kepada masyarakat lainnya sebagai anugerah Allah. Ketiga, menanamkan akhlak dan nilai-nilai Islam kepada masyarakat dan sekitarnya. Dengan demikian, tujuan dan guna adat dalihan na tolu adalah supaya masyarakat dapat mencerminkan nilai-nilai akhlaknya untuk hari ke depan dan dapat pula menanamkan nilai-nilai Islam kepada masyarakat sekitar, dapat juga mempersatukan dan memperkuat hubungan silaturahmi dengan masyarakat lain.

\section{Harangan Rarangan}

Konsep melindungi sumber daya alam agar tetap terpelihara dengan baik, bukan hal baru bagi masyarakat Muslim Mandailing. Kearifan lokal sejak dulu sudah ada di masyarakat Mandailing seperti harangan yakni kawasan hutan yang ditetapkan sebagai sumber kebutuhan non kayu seperti obat, tempat berburu, damar, madu, sayuran, aren, dan bahan bangunan. Khusus untuk kawasan hutan tertentu ada yang disebut harangan rarangan, yaitu hutan larangan. Hutan larangan dalam konsepsi tradisional adalah bagian dari suatu kawasan hutan milik suatu kampung yang tidak boleh dibuka untuk lahan pertanian. Kayu dalam hutan larangan juga tidak boleh diambil untuk keperluan domestik dan komersil. Selain pada lingkungan hutan, konsep rarangan tersebut juga berlaku untuk suatu kawasan tertentu di kawasan bagian aliran sungai. Bagian-bagian yang biasa terlarang bagi penduduk untuk menangkap ikan di sungai dan terdapat pohon-pohon besar yang berdaun rimbun. Kawasan demikian (daerah-daerah terlarang tersebut) biasa juga dipercaya sebagai tempat yang dihuni oleh makhluk-makhluk halus, biasa disebut naborgo-borgo, artinya adalah yang lembab-lembab. Ada kepercayaan bahwa merupakan hal yang tabu untuk memasuki tempat-tempat terlarang, dan akan menyebabkan petaka bagi pelakunya.

Sikap yang ditumbuhkan dari harangan rarangan, maka kerusakan hutan secara liar tidak akan terjadi, tetapi hal ini tidak tercipta karena memang di daerah Mandailing sendiri sudah berbaur dengan masyarakat luar dan nilai-nilai dalihan na tolu sudah mulai pudar, sehingga perlu tetap dipertahankan untuk menjaga harmonisasi lingkungan hidup.

Menurut Hasibuan, pengarang buku Dalihan Na Tolu, mengungkapkan bahwa:

Nilai-nilai yang terdapat pada dalihan na tolu merupakan nilai-nilai mulia yang akan menjaga dan menolong sesamanya, tetapi banyak dari kita tidak memahami dan tidak ingin tahu karena sudah terbias pengaruh modernisasi yang membuat mereka tidak lagi memamahami nilai-nilai luhur dari nenek moyang kita yang perlu dilestarikan karena memuat nilai-nilai moral. ${ }^{24}$

Sifat melindungi hutan (harangan rarangan) sesuai firman Allah SWT, berikut: h. 55 .

${ }^{24}$ Zainal Efendi Hasibuan dan Perkasa Alam, Studi Komprehensif Adat Budaya Batak Angkola, 
Danjanganlah kamu berbuat kerusakan di bumi setelah (diciptakan) dengan baik. Berdoalah kepada-Nya dengan rasa takut dan penuh harap. Sesungguhnya rahmat Allah sangat dekat kepada orang yang berbuat kebaikan. Dialah yang meniupkan angin sebagai pembawa kabar gembira, mendahului kedatangan rahmat-Nya (hujan), sehingga apabila angin itu telah membawa awan mendung, Kami halau ke suatu daerahyang tandus, lalu Kami turunkan hujan di daerah itu. Kemudian Kami tumbuhkan dengan hujan itu berbagai macam buahbuahan. Seperti itulah Kami membangkitkan orang yang telah mati, mudah-mudahan kamu mengambil pelajaran. Dan tanah yang baik, tanaman-tanamannya subur dengan izin Tuhan; dan tanah yang buruk, tanaman-tanamannya yang tumbuh merana. Demikianlah kami menjelaskan berulang-ulang tanda-tanda (kebesaran Kami) bagi orang-orangyang bersyukur (Q.S. al-A'râf/7: 56-58). ${ }^{25}$

Ayat tersebut memerintahkan manusia agar tidak membuat kerusakan di muka bumi, tetapi manusia diciptakan sebagai khalifah yang bertugas menjaga ciptaan-Nya. Hal tersebut jangan sampai dilanggar karena akan memberikan efek kepada manusia. Manusia harus bersyukur atas nikmat Allah di muka bumi. Tetapi pada kenyataannya sudah banyak yang dilanggar, misalnya harangan rarangan di masyarakat Mandailing Natal adalah Taman Nasional Batang Gadis (TNBG) yang diharapkan sebagai perlindungan hutan, sumber air sudah dirusak oleh penambang emas liar di wilayah TNBG. Sangat diperlukan kearifan lokal dalihan na tolu untuk melindungi kembali supaya tidak terjadi longsor ataupun banjir akibat kerusakan hutan tersebut.

Selain itu, wawancara dengan Muksin Lubis, menyebutkan dengan dalihan na tolu akan tercipta organisasi masyarakat berdasarkan marga misalnya Lubis, Nasution atau lainnya, sehingga organisasi yang terbentuk ini kian hari kian besar, sehingga bila disatukan dengan organisasi marga lainnya yang sifatnya bisa sebagai mora, kahanggi ataupun anak boru yang menyebabkan semua pekerjaan akan lebih mudah dilaksanakan. ${ }^{26}$ Begitu juga dengan Zainal Efendi menyampaikan bahwa adat dalihan na tolu merupakan kearifan lokal yang memiliki keseimbangan, sehingga apabila ada badai atau rintangan menerpa dengan kokoh ikatan tersebut akan bertahan. Untuk itu dengan menumbuhkan sifat harangan rarangan, maka kelestarian lingkungan tetap terjaga. ${ }^{27}$

\section{Lubuk Larangan}

Lubuk larangan adalah satu bagian dari aliran sungai yang di dalamnya terlarang untuk melakukan aktivitas penangkapan semua jenis ikan sungai dalam jangka waktu tertentu. Pengelolaan lubuk larangan melalui konservasi berjangka terhadap ikan sungai dilakukan sebagai upaya komunitas desa menghimpun modal untuk pembangunan desa.

${ }^{25}$ Departemen Agama RI, Al-Qur'an dan Terjemahannya, h. 212.

${ }^{26}$ Muksin Lubis, salah satu hatobangon di Mandailing, Wawancara, Minggu, 28 Juni 2015.

${ }^{27}$ Zainal Efendi, Wawancara, Senin, tanggal 8 Juni 2015. 
Rekayasa sosial budaya dibuat di tingkat komunitas sebagai basis ideologis terhadap tindakan konservasi melalui model lubuk larangan.

Akibat baik yang ditimbulkan dari kepercayaan dan praktik lubuk larangan ini adalah terpeliharanya kesinambungan sumber daya ikan sungai karena terjaganya proses reproduksi ikan. Keuntungan lain yang diperoleh masyarakat (di mana umumnya masyarakat Mandailing adalah petani tanaman pangan dan berkebun yang sangat bergantung dengan alam) adalah terpeliharanya sumber-sumber air untuk mengairi pertanian karena terpeliharanya rimbunan hutan di daerah hulu sungai dan badan sungai. Air merupakan sumber kehidupan bagi masyarakat Mandailing Natal yang sekaligus tali-temali dengan institusi sosial, budaya, ekonomi dan ekologis. Berbagai teknik penangkapan ikan dari yang sangat bernuansa kearifan lokal seperti memancing dan pasang bubu (perangkap ikan) sampai yang bernuansa eksploitasi, seperti menuba (meracuni ikan) bahkan membom ikan. Hal ini bisa terjadi karena aliran sungai dipandang sebagai sumber daya yang bersifat open source atau open access. Lubuk larangan produk adat yang sampai saat ini masih dipertahankan berupa keberadaan air dan ikan sepanjang sungai yang tidak boleh diganggu dan dipanen karena untuk kepentingan sosial keagamaan, bagi yang melanggar akan terkena sanksi atau sakit. Lubuk larangan biasanya dipanen sekali setahun atau dua kali setahun tergantung mufakat bersama di desa, waktu panen saat acara khusus seperti Idul Fitri dan hasil penjualan tiket digunakan untuk kepentingan masyarakat bersama seperti membangun masjid, dan untuk anak yatim.

Setiap huta atau banua yang dipimpin oleh seorang raja pamusuk atau raja panusunan bulung di masa lampau harus memiliki wilayah sendiri, yang tergambar dalam istilah ganop-ganop banua martano rura yang berarti setiap kerajaan memiliki wilayah tanah airnya sendiri. Setiap huta atau banua harus memiliki dan ditopang oleh adanya sumber air, kawasan hutan dan juga padang penggembalaan. Sebagian dari kawasan itu ditetapkan oleh pimpinan komunitas sebagai kawasan rarangan atau kawasan konservasi menurut istilah sekarang. ${ }^{28}$

Hasil wawancara dengan Muksin Lubis (Hatobangon), dikatakan bahwa "lubuk larangan di masyarakat Mandailing terus dilakukan untuk meningkatkan kebersamaan sehingga bila panen tiba, maka semua anggota yang ikut menanamkan benih akan mendapat hasil sama rata. ${ }^{29}$ Selanjutnya hasil wawancara dengan Tongku Saypuddin, menyebutkan bahwa lubuk larangan terbentuk karena adanya ikatan dalihan na tolu yaitu kerja sama yang kuat antar sesama dalam masyarakat tersebut. Berbeda dengan konsep lubuk larangan berbasis kepercayaan di masa lampau, model lubuk larangan yang tumbuh sejak tahun 1980-an dikelola dengan pendekatan rasional dan dengan satu tujuan yang jelas. Tujuan

${ }^{28}$ Edi Ikhsan dan Zulkifli Lubis, et al., "Dari Hutan Rarangan ke Taman Nasional: Potret Komunitas Lokal di Sekitar Taman Nasional Batang Gadis," dalam Bitra Konsorsium, Medan, 2005.

${ }^{29}$ Muksin Lubis, Hatobangon, Wawancara, Minggu, pada tanggal 28 Juni 2015. 
utamanya adalah pembiakan dan pembesaran ikan-ikan sungai dalam jangka waktu tertentu (sekitar setahun), sehingga pada akhir periode penutupan lubuk larangan sudah cukup baik untuk dipanen. Asumsinya, selama pemeliharaan satu tahun benih ikan di dalam sungai akan berkembang dengan baik dan bertambah banyak. Proses alamiah itu didukung dengan usaha pemeliharaan (misal dengan memberikan pakan) dan penjagaan (dengan regu jaga dan penjagaan secara gaib) oleh panitia agar terhindar dari aktivitas pencurian. ${ }^{30}$

Lubuk larangan dapat menghindari berbagai teknik penangkapan ikan yang bernuansa eksploitasi seperti menuba, dan menangkap ikan dengan bahan peledak, sehingga ketersediaaan sumber daya ikan dapat dijaga kesinambungannya, atau dengan teknik pemanenan dalam satu kali dalam satu tahun atau dua kali dalam setahun hasilnya akan lebih banyak dan dapat digunakan untuk kepentingan masyarakat bersama.

\section{Bahasa Daun}

Masyarakat Mandailing mempunyai filosofi yang mendasari sikap dan perilaku mereka bergaul dengan alam, sehingga pada dasarnya mereka adalah pecinta dan pelestari lingkungan. Kosa kata bahasa daun masyarakat Mandailing sesuai dengan nama daun tersebut di mana jenis-jenis daun tersebar di dalam kawasan hutan Mandailing. Menurut C.A. Van Ophuysen, orang Mandailing adalah satu-satunya suku bangsa yang memiliki bahasa daun. Keberadaan bahasa daun mengisyaratkan betapa orang Mandailing dekat dengan alam, sehingga mereka pada dasarnya adalah pecinta dan pelestari alam sehingga tercapai ekologi alam dan manusia yang seimbang. Kearifan lokal tersebut menunjukkan bahwa masyarakat Mandailing Natal yang peduli lingkungan, peka, dan arif terhadap pelestarian alam termasuk hutan dan sumber daya airnya. ${ }^{31}$

Inti ajaran dalihan na tolu adalah kaidah moral berisi ajaran saling menghormati (masipasangapon) dengan dukungan kaidah moral: saling menghargai dan menolong. dalihan na tolu adalah suatu bentuk nilai budaya Batak salah satunya masyarakat Mandailing. Hal ini yang menyebabkan diperlukannya pemahaman mengenai dalihan na tolu oleh setiap individu dalam masyarakat Mandailing. Masyarakat Mandailing dewasa ini berada pada situasi budaya kenyataan. Kenyataan sosial budaya tersebut berhadapan dengan keindahankeindahan budaya yang ditampilkan sebagai identitas yang mengandung esensi keinginan, harapan, atau idealisme yang diwarisi dari nenek moyang namun pada kenyataannya sudah banyak yang berubah.

Mekanisme dalihan na tolu berfungsi memelihara kesatuan (integrasi) masyarakat Mandailing. Hal tersebut dapat berlangsung karena keluarga inti menjalankan fungsifungsi hula-hula, dongan tubu, boru pada tempat, waktu, dan konteks peristiwa dan dengan

\footnotetext{
${ }^{30}$ Tongku Saypuddin, Tokoh Adat, Wawancara, Minggu tanggal 01 Juni 2015.

${ }^{31}$ Lihat Abbas Pulungan, "Peranan Dalihan Natolu dalam Proses Interaksi Antara Nilai-Nilai Adat dengan Islam pada Masyarakat Mandailing dan Angkola Tapanuli Selatan."
} 
cara yang benar. Fungsinya kalau hula-hula memberi pengayoman dan dongan sabutuha menanggung bersama beban ringan maupun berat sedangkan boru "berkorban" untuk hula-hula.

Dalihan na tolu dapat dikategorikan sebagai wujud kebudayaan ideas, karena sebagai ideas dalihan na tolu merupakan suatu gagasan yang merupakan nilai inti dari masyarakat. Kebudayaan masyarakat Mandailing tersebut sifatnya sangat abstrak, tidak dapat diraba maupun difoto. Lokasinya berada dalam alam pikiran warga masyarakat itu sendiri. Gagasangagasan itu tidak berada lepas dari yang lain, melainkan selalu berkaitan, menjadi suatu sistem atau adat istiadat.

Dengan menanamkan nilai-nilai dalam dalihan na tolu, maka adat dan agama akan bersama-sama dalam membentuk masyarakat untuk meningkatkan kebersamaan, perilaku berkarya dan karya cipta yang akan mendukung harmonisasi lingkungan hidup yaitu pembiasaan-pembiasaan yang diciptakan dari kebersamaan yang bertujuan melindungi diri dan lingkungannya dengan marsiapari, harangan rarangan, lubuk larangan dan bahasa daun.

Seiring dengan perkembangan era globalisasi, aspek kebudayaan juga mengalami perkembangan yang cukup pesat karena merupakan bagian penting dalam ilmu pengetahuan dan keterkaitannya dengan hubungan sosial kemanusiaan. Perkembangan budaya yang terjadi juga tidak terlepas dari upaya peningkatan kesadaran akan keanekaragaman budaya tersebut. Keterkaitan potensi atau aspek budaya ini merupakan suatu hal yang masih perlu dikembangkan terutama dalam perwujudannya dan kelestarian lingkungan hidup.

\section{Cara Mempertahankan Kearifan Lokal Dalihan Natolu dalam Menjaga Keharmonisan Lingkungan Hidup}

\section{Meningkatkan Proses Sosialisasi Dalihan Na Tolu}

Semakin banyak organisasi masyarakat yang dilibatkan oleh individu, maka semakin tinggi proses sosialisasi; semakin banyak teman bermain yang bersuku Mandailing, maka proses sosialisasi akan semakin tinggi, mengingat masyarkat sekarang adalah masyarakat heterogen sehingga tidak terjadi pembauran budaya. Proses sosialisasi dalihan na tolu juga penting dalam mempersiapkan generasi muda sebagai penerus agar kebudayaan tersebut tidak punah dan dapat dijadikan filtrasi dalam menghadapi perubahan kebudayaan. Proses sosialisasi tersebut dapat dilakukan dengan pengendalian sosial yaitu melalui proses ajar didik, sanksi, ritus kolektif dan alokasi posisi.

Dari hasil wawancara dengan Nurhidayah Nasution (masyarakat Mandailing), dinyatakan bahwa masyarakat Mandailing memiliki marga, dan setiap marga akan membentuk komunitasnya (organisasi) yang pada intinya setiap kegiatan yang akan dilakukan individu, maka komunitas satu marga akan ikut terlibat, dan di samping itu juga marga 
lain yang terlibat ikatan persaudaraaan seperti dalihan natolu mora, kahanggi ataupun anak boru. ${ }^{32}$

Sosialisasi terhadap dalihan na tolu dilakukan dengan sistem pengendalian sosial. Pengendalian sosial dilakukan dengan empat komponen, yaitu proses ajar didik, sanksi, alokasi posisi, ritus kolektif. Pengendalian sosial yang dilakukan mempengaruhi perilaku generasi muda terhadap dalihan na tolu.

Masyarakat yang ideal menurut Mandailing adalah masyarakat yang di dalam interaksi sosialnya ditemukan holong (kasih sayang). Holong dijadikan sumber semua kehidupan. Karena itu ada istilah dalam Mandailing, holong do mula ni ugari (kasih sayang awal dari adat), atau holong do maroban domu, domu maroban parsaulian (kasih sayang membawa keakraban, keakraban membawa kebaikan bersama). Dengan masyarakat sosial yang tinggi, maka tingkat kebersamaan juga akan semakin tinggi, sehingga nilai-nilai gotong royong, bekerjasama, saling membantu dan saling melindungi akan tercipta mewujudkan masyarakat yang harmonis begitu juga dengan lingkungan hidupnya.

\section{Kurikulum Pendidikan}

Memasukkan kearifan lokal daerah dalam kurikulum bagi siswa SD sampai SMU sederajat atau mata kuliah untuk mahasiswa sehingga nilai-nilai luhur yang diwariskan nenek moyang tidak hilang atau terpengaruh dari budaya luar. Suatu suku bangsa akan lenyap bilamana mereka tidak memiliki pegangan dalam mengatur kehidupan bermasyarakat. Pegangan dimaksud adalah adat budaya yang terdapat pada suatu masyarakat. Karena itu, nilai adat budaya perlu dikenalkan agar masyarakat sekarang dan yang akan datang mampu berperilaku sesuai tuntutan adat budaya yang dijunjung. mengajarkan adat budaya kepada generasi muda selain sebagai sumbangan nyata, juga sebagai upaya mem-bantu tegaknya tata-tertib sosial kepada angkatan muda. Pengalaman pahit atau manis yang dialami oleh satu suku bangsa memang dapat mengembangkan nilai adat yang dilakukannya dan sejauhmana konsistensi dengan nilai adatnya.

Dalam kaitan itulah mengapa adat dalihan na tolu diajarkan di lingkungan pendidikan. Ia merupakan adat istiadat yang bertalian erat dengan sistem kekerabatan. Dengan perkawinan terjadilah ikatan dan integrasi di antara tiga pihak yang disebut tadi, seolah-olah mereka bagai tiga tungku dapur yang besar gunanya dalam menjawab persoalan hidup sehari-hari. Cukup banyak fungsi adat ini bagi masyarakat pendukungnya, di antaranya pati dohot holong yang artinya menunjukan kasih sayang di antara sesama yang penuh sopan santun/etika. Dari fungsinya yang penuh kehormatan, adat dalihan na tolu dapat diterima oleh setiap masyarakat Mandailing sekalipun mereka berbeda-beda agama. Mereka yang menganut agama Islam, Kristen, Katolik, dan Buddha kadang-kadang begitu erat ikatannya karena

${ }^{32}$ Nurhidayah Nasution, Tokoh Masyarakat Mandailing, Wawancara, Selasa, 23 Juni 2015. 
konsep adat telah terbentuk sejak mulai lahirnya kelompok masyarakat yang identitas utamanya adalah adanya marga. Dengan marga itu, orang Mandailing akan setia tehadap ketentuan adatnya di mana pun mereka berada.

\section{Penanaman Nilai-nilai Agama}

Penanaman nilai-nilai agama merupakan faktor utama dalam melestarikan kearifan lokal dalihan na tolu. Dengan tetap berpedoman terhadap al-Qur'an dan hadis, maka nilainilai yang tertanam dalam dalihan na tolu akan terjaga dan terlaksana dalam setiap kehidupan bermasyarakat maupun terhadap lingkungan.

Manusia adalah makhluk hidup yang diciptakan oleh Allah SWT. untuk tinggal di bumi, beraktivitas dan berinteraksi dengan lingkungannya dengan masa dan relung waktu terbatas. Firman Allah Swt dalam Q.S. al-Baqarah/2:36, "Lalu keduanya digelincirkan oleh syaitan dari surga itu dan dikeluarkan dari keadaan semula dan Kami berfirman: Turunlah kamu! sebagian kamu menjadi musuh bagi yang lain, dan bagi kamu ada tempat kediaman di bumi, dan kesenangan hidup sampai waktu yang ditentukan."

Kediaman di muka bumi diberikan Allah kepada manusia sebagai suatu amanah. Manusia wajib memeliharanya sebagai suatu amanah. Manusia telah diberitahu oleh Allah bahwa mereka akan hidup dalam batas waktu tertentu. Karena itu, manusia dilarang keras berbuat kerusakan. Dengan kedudukan manusia sebagai khalifah di muka bumi ini, sebenarnya manusia telah diberi tanggungjawab besar, yaitu diserahi bumi ini dengan segala isinya. Apa yang telah ditegaskan Allah dalam firman-Nya di atas adalah untuk mengingatkan manusia agar bersyukur. Karena walaupun manusia diciptakan melebihi makhluk lain, manusia tidak mampu memenuhi keperluannya sendiri tanpa bahan-bahan yang disediakan. Hal ini perlu disadari oleh manusia, sebab tanpa memiliki rasa dan sikap syukur kepada Allah, maka manusia cenderung akan merusak. Dalam konteks mensyukuri nikmat Allah atas segala sesuatu yang ada di alam ini untuk manusia, menjaga kelestarian alam bagi umat Islam merupakan upaya untuk menjaga limpahan nikmat Allah secara berkesinambungan. Sebaliknya, membuat kerusakan di muka bumi, akan mengakibatkan timbulnya bencana terhadap manusia. Allah sendiri membenci orang-orang yang membuat kerusakan di muka bumi.

\section{Penutup}

Kearifan lokal dalihan na tolu masyarakat Muslim Mandailing menghasilkan sikap kebersamaan atau semangat gotong royong, memiliki hak dan kewajiban yang sama dan menghasilkan karya cipta dalam menjaga keharmonisan lingkungan hidup dengan mengembangkan sikap marsialapari, harangan rarangan, lubuk larangan, dan bahasa daun. Dalam mengembangkan sikap kearifan lokal dalihan na tolu, maka sangat perlu mensosialisasikan bagi generasi muda dan menumbuhkan pengetahuan tentang kearifan lokal sejak dini mulai dari sekolah dasar sampai perguruan tinggi, sehingga nilai-nilai luhur dari kearifan lokal tidak 
terdegradasi dengan perkembangan zaman. Kearifan lokal dalihan na tolu masyarakat Muslim Mandailing tidak terlepas dari nilai-nilai Islam yang bersumber dari al-Qur'an dan hadis. Sebagai saran, ditegaskan bahwa perlu dilakukan penelitian lanjutan untuk meneliti kearifan lokal lain dalam masyarakat sehingga dapat dihubungkan dengan penelitian ini, dan perlu dianalisa perbedaan paham keagamaan tentang kebudayaan dalam masyarakat

\section{Pustaka Acuan}

Alam, T.B.P. Burangir Nahombang. Jakarta: Depdikbud, 1981.

Bulmer, R.N.H, “Traditional Conservation Practices in Papua New Guinea," dalam L. Morauta, et al. (ed.), Traditional Conservation in Papua New Guinea: Implication for Today. T.t.p.: PNG, 2013.

Ikhsan, Edi dan Zulkifli Lubis, et al. "Dari Hutan Rarangan ke Taman Nasional: Potret Komunitas Lokal di Sekitar Taman Nasional Batang Gadis," dalam Bitra Konsorsium, Medan, 2005.

Ferrari, Maurizio Farhan. "Community Conserved Areas in Southeast Asia," dalam Final Report for IUCN, 2002.

Harahap, Basyral Hamidy. Siala Sampagul (Nilai-Nilai Luhur Budaya Masyarakat Kota Padangsidimpuan). Bandung: Pustaka, 2004.

Harahap, Basyral Hamidy dan Hotman Siahaan. Orientasi Nilai-Nilai Budaya Batak. Jakarta: Sanggar William Iskandar, 1987.

Hasibuan, Zainal Efendi dan S.T.B. Perkasa Alam. Studi Komprehensif Adat Budaya Batak Angkola. t.t.p.: t.p., 2013.

Koentjaraningrat. Pengantar Ilmu Antropologi. Jakarta: Rineka Cipta, 1990.

Moleong, Lexy J. Metodologi Kualitatif. Bandung: Remaja Rosda Karya, 2004.

Nasution, Pandapotan. Uraian Singkat tentang Adat Mandailing dan Tata Cara Perkawinannya. Jakarta: Widya Press, 1994.

Lubis, Rosliana. "Partuturon dalam Masyarakat Angkola," dalam Jurnal Ilmiah Bahasa dan Sastra, Vol. II, No. 1, April, 2006.

Pulungan, Abbas. "Peranan Dalihan Natolu dalam Proses Interaksi Antara Nilai-Nilai Adat dengan Islam pada Masyarakat Mandailing dan Angkola Tapanuli Selatan.” Disertasi: IAIN Suanan Kalijaga Yogyakarta, 2003.

Suhartini. "Kajian Kearifan Lokal Masyarakat dalam Pengelolaan Sumber Daya Alam dan Lingkungan," Makalah Prosiding Seminar Nasional Penelitian, Pendidikan dan Penerapan MIPA, Fakultas MIPA, Universitas Negeri Yogyakarta, 16 Mei 2009.

Tim Penyusun Kamus Pusat Bahasa. Kamus Besar Bahasa Indonesia. Jakarta: Balai Pustaka, 2005.

Tim Penulis Parsadaan Marga Harahap Dohot Anak Boruna. Horja Adat Istiadat Dalihan Natolu. Jakarta: Persadaan Marga Harahap Dohot Boruna, 1991. 